\title{
IMPLEMENTASI POLIGAMI ANTINOMI ANTARA INDIVIDUAL RIGHT DAN SOCIAL RIGHT
}

\author{
Oleh: \\ Sanyoto \\ Fakultas Hukum Universitas Jenderal Soedirman
}

\begin{abstract}
Court of religion have absolute jurisdiction to check and judge polygamy application and then check the material condition and if its fulfilled, husband as applicant obliged to prove the reason. If he success to prove, so there are polygamous permission, but if he fail to prove the reason of polygamy, so the application will be refused. In application of Polygamy, Religion court give register of polygamous permission in form Pdt G. Verification charged upon husband. Wife have to explain about polygamous permission which given this matter shows importance antinomy between Wife, Husband, and society. Polygamous Implementation in Religion court have done according to existing rule, but for this decision many people is disgruntled because its sacrifice the justice for wife.
\end{abstract}

Kata Kunci: Poligami, Antinomi

\section{A. Pendahuluan}

Implementasi atas Undang Undang Perkawinan No. 1 Tahun 1974 dengan sebagai peratuan pelaksanaannya khususnya tentang poligami dalam kehidupan masyarakat sampai saat ini terdapat beberapa tantangan yang secara langsung maupun tidak langsung dari internal maupun eksternal dan menimbulkan polemik dan membutuhkan solusi. Ungkapan yang umum pada dasarnya hukum akan menjadi baik apabila masyarakat menerimanya dengan melaksanakan secara suka rela, sedang sebaliknya hukum menjadi tidak baik apabila masyarakat tidak dapat menerimannya karena tidak sesuai dengan kepentingannya.

Poligami dari dulu sampai sekarang telah menjadi fenomena yang menarik dan ada yang melakukan dengan secara legal, dan ada pula yang melakukan secara tidak legal dalam arti tidak dicatatkan. Kedua hal tersebut tentu bila dikatakan menurut ketentuan hukum mempunyai akibat hukum yang berbeda.

Undang-Undang Perkawinan pada asasnya menganut asas monogami sedangkan poligami sebagai pengecualian, bila memenuhi syarat materiil maupun formal. Undang-Undang Perkawinan (UU No. 1 Tahun 1974) pada Pasal (1) menentukan bahwa, "Perkawinan adalah ikatan lahir batin antara seorang pria dengan seorang wanita sebagai suami istri dengan tujuan membentuk keluarga yang bahagia dan kekal berdasarkan ke Tuhanan Yang Maha Esa". Pasal 3 ayat (1) "Pada asasnya dalam suatu perkawinan seorang pria hanya boleh mempunyai seorang istri, seorang wanita hanya boleh mempunyai seorang suami".

Hal ini menunjukan bahwa dengan istilah pada asasnya berarti boleh ada penyimpangan, hal ini ternyata dalam ayat (2) yang memberikan ketentuan bahwa pengadilan "dapat" memberikan ijinpada seorang suami untuk beristri lebih dari seorang, apabila dikehendaki oleh pihak-pihak yang bersangkutan.

Kemudian pada Pasal 3 ayat (2) ditentukan bahwa Pengadilan dapat memberikan izin kepada seorang suami untuk beristri lebih dari seorang apabila dikehendaki oleh pihak-pihak yang bersangkutan.

Pasal 4 ayat (2) juga menentukan bahwa Pengadilan hanya memberikan izin kepada seorang suami yang akan beristri lebih dari seorang apabila :

a. Istri tidak dapat menjalankan kewajibannya sebagai istri;

b. Istri mendapat cacad badab atau penyakit yang tidak dapat disembuhkan; 
c. Istri tidak dapat melahirkan keturunan.

Kemudian Pasal 5 menyatakan untuk dapat mengajukan permohonan kepada pengadilan sebagaimana dimaksud Pasal 4 ayat

(1) harus dipenuhi syarat sebagai berikut:

a. Adanya persetujuan dari isteri-isteri

b. Adanya kepastian bahwa suami mampu menjamin keperluan-keperluan hidup isteriisteri dan anak-anak mereka

c. Adanya jaminan bahwa suami akan berlaku adil terhadap isteri-isteri dan anak-anak mereka.

Kehendak untuk melakukan poligami dimanapun dan kapanpun meski hukum menentukan adanya syarat yang relatif sulit dipenuhi oleh suami yang tujuannya membentuknya sifatnya untuk mencegah (preventif) ataupun menentukan tindakan preventif dalam arti mengambil tindakan bila dilanggar, dalam implementasi oleh pengadilan menunjukan adanya antinomi antara aspek kepastian hukum, keadilan dan pemanfaatan bagi kepentingan pribadi suami (individual right) atau istri dan keluarga dan masyarakat (Social Right).

Permohonan izin poligami yang diajukan suami disamping harus mempunyai alasan dan syarat menurut Undang -Undang yakni adanya persetujuan dari istri serta harus mampu berbuat adil terhadap istri-istri dan anakanaknya. Pengadilan sebagai lembaga yang diberi kewenangan untuk memeriksa, mengadili dan memutuskan adanya permahonan izin poligami yang diajukan hakimnya diharapkan sikapnya tidak memihak (imparsial) dalam memutuskan apakah akan mengabulkan ataukah akan menolak.

Berdasarkan hal tersebut di atas, penulis tertarik untuk membahas mengenai fungsi dan peran hakim dalam menghadapi adanya antinomy kepentingan dalam memeriksa permohonan poligami.

\section{B. Pembahasan}

Fungsi Pengadilan Agama sebagai sebuah konstitusi dapat ditinjau dari berbagai fungsi. Pertama dari segi tujuan bernegara, Negara dan pemerintahan Republik Indonesia didirikan sebagimana dirumuskan dalam Undang-Undang
Dasar 1945 tujuannya antara lain memajukan kesejahteraan umum dalam wujud kemakmuran sebesar-besarnya kemakmuran dan keadilan sosial bagi seluruh rakyat Indonesia. Tujuan ini melekat juga pada pengadilan sebagai institusi yang menjalankan fungsi Negara. Pengertian kesejahteraan, kemakmuran, dan keadilan sosial tidak semata-mata dalam ari ekonomi melainkan juga meliputi juga hal-hal seperti pelaksanaan hukum yang baik, perlindungan hukum atas segala hal perseorangan atau kelompok masyarakat dan memperoleh perlakuan dan kesempatan yang sama tanpa membedakan kedudukan dan latar belakang.

Kedua, mewujudkan tujuan-tujuan hukum seperti keadilan, ketertiban, keseimbangan sosial, kepuasaan pencari keadilan dan lainlain. Fungsi ini dipandang sebagai tradisional pengadilan dan peradilan, sebagai suatu keharusan tetapi sangat sulit diwujudkan. Berbagai tujuan hukum tersebut tidak selalu berjalan seiring, pada waktu dan keadaan tertentu dapat berbeda bahkan mungkin bertentangan satu sama lain. Misalnya antara keadilan dan ketertiban. Keadilan pada umumnya bersifat kasusistik yang bersifat individual, sedangkan ketertiban biasanya bersifat untuk kepentingan orang banyak dan bersifat rata-rata (openbaar orde public order). Ada kemungkinan demi memenuhi ketertiban akan mengurangi sifat dan tuntutan keadilan. Begitu juga antara kepuasan individual dan keseimbangan sosial dimana adakalanya kepuasaan individual dikurangi atau bahkan dikorbankan. Kadang-kadang bermacam-macam tujuan dituntut sekaligus tanpa mengetahui perbedaan-perbedaannya, yang penting masyarakat tertarik semata-mata membangkitkan "social sentiment atau social solidarity" tanpa memperhitungkan cara mewujudakan apalagi hasilnya. Perbedaan-perbedaan yang berseberangan satu sama lain diperlukan kejernihan masing-masing disesuaikan dengan tempat tuntutan supaya jangan bercampur aduk.

Ketiga, segi penegakan hukum esensinya menegakkan hukum adalah menjalankan dan mempertahankan hukum. Konsekuensi men- 
jalankan hukum dan mempertahankan hukum, pengadilan dan peradilan wajib memutus menurut hukum.

Praktek keharusan memutus menurut hukum acapkali menghadapkan pengadilan dan peradilan pada aneka ragam makna hukum. Pemaknaan atas hukum sebagai pengertian :

1. Makna normatif memunculkan berbagai pandangan mengenai esensi dan subtansi hukum yakni hukum diartikan sebagai aturan tertulis. Pada pengertian ini tidak semua masalah hukum dimuat dalam aturan tertulis.

Ketika hukum diartikan sebagai aturan tertulis dan tidak tertulis tidak serta merta memudahkan untuk menerapkan karena doktrin mengajarkan kalau ada pertentangan antara yang tertulis dan yang tidak tertulis, maka hukum tertulislah yang diutamakan (Prevail). Persoalan lebih lanjut kalau ternyata hukum tidak tertulis lebih disesuaikan dengan kesadaran hukum atas rasa keadilan atau kenyataan yang hidup dalam masyarakat. Hukum tidak tertulis merupakan "the living law" sedang secara sosial hukum tertulis merupakan "The dead law". Perkembangan yang lain berpendapat agar kenyataan sosial harus menjadi dasar yang dipertimbangkan pengadilan dan peradilan. Hakim dapat mengesampingkan hukum apabila tidak sesuai dengan kenyataan sosial. Tetapi sebaliknya bila terlalu mengutamakan kenyataan sosial akan menimbulkan ketidakpastian hukum dan penerapan hukum menjadi sangat subyektif. Kedua persoalan itu mengakibatkan rendahnya konsistensi dan sulit melakukan prediksi dalam penerapan hukum.

2. Hukum diartikan sebagai gejala sosial artinya hukum diartikan sebagai tingkah laku warga masyarakat. Ada juga yang mengartikan sangat luas yaitu setiap aturan tingkah laku adalah hukum termasuk kewajibannya yang bersifat kesusilaan, kebiasaan-kebiasaan. Dalam bahasa masyarakat adat, hukum adalah segala sesuatu yang diadatkan. Ada juga yang mengartikan secara sempit yaitu batas pada aturan tingkah laku yang bersanksi. Atas hal ini hakim menghadapi masalah yakni: Pertama aturan tingkah laku antara satu tempat dan tempat lain adalah berbeda-beda. Kedua tidak mudah menentukan apakah suatu hukum atau aturan tingkah laku masih bener-bener hidup atau sudah ditinggalkan dan hanya mempunyai nilai sejarah saja.

3. Memberi arti luas terhadap hukum atau aturan tingkah laku seperti persoalan kenyataan sosial masyarakat dapat menyebabkan penerapan hukum menjadi sangat subyektif tergantung penemuan hukum hakim yang bersangkutan. Hal ini akan berpengaruh pada tuntutan konsistensi, kepastian dan dasar-dasar prediksibilitas aturan hukum. Sebaliknya bila hukum diberi arti yang sempit yaitu sebagai aturan tingkah laku yang bersanksi. Pengertian sosial mengenai sanksi berbeda dengan pengertian normative baik untuk kepastian, konsistensi dan prediksibilitas, sanksi harus definitive baik bentuk isi maupun lingkupnya.

Konsep-konsep yang kompleks tersebut diatas berhadapan dengan aturan hukum yang kompleks, peristiwa hukum yang kompleks dan kepentingan yang berbeda dan bahkan ada kemungkinan bertentangan satu sama lain. Problema penegakan hukum nampak mulai menghadapi kendala berkaitan dengan perkembangan masyarakat, sebagaimana ungkapan ahli menyatakan bahwa hukum mengikuti perkembangan dan tidak pernah mendahului perkembangan masyarakat. Dengan kata lain hukum selalu mengikuti dari belakang. ${ }^{1}$

Dalam fungsinya sebagai pelindung kepentingan manusia, hukum mempunyai tujuan. Adapun tujuan pokok hukum adalah menciptakan tatanan masyarakat yang tertib dengan konsekuensi kepentingan manusia menjadi terlindungi (individual right), tetapi juga kepentingan masyarakat/kolektif (social right). Asas kolektif jelas bertentangan dengan asas individualis. Dalam teori hukum disebut

Wantu, fence M, 2007, Antinomi dalam Penegakan Hukum, Mimbar Hukum, vol 19 No. 3, hlm. 335 
sebagai antinomi yakni kondisi yang saling bertentangan satu sama lain, akan tetapi tidak dapat dipisahkan karena sama-sama saling membutuhkan. ${ }^{2}$

Hakim acapkali harus berhati-hati dalam memutus perkara poligami serta tidak boleh menyederhanakan persoalan hukum yang sedang diperiksanya karena apa yang diputuskan akan memberikan pengaruh baik positif atau negatif. Bila dalam mengambil keputusan dalam bentuk penetapan semata-mata bertolak untuk kepentingan publik (masyarakat) maka hakim dituntut melakukan rekayasa hukum tanpa perlu memperhatikan syarat-syarat, serta cara-cara yang ditentukan oleh hukum yang sifatnya kaku, bahkan bila perlu aturan hukum dikesampingkan demi kepentingan publik. Keadaan seperti ini nampaknya, merupakan fenomena dimana tujuan menghalalkan cara (the and justifes the mean). ${ }^{3}$

Hakim dalam persoalan ini seharusnya tetap memperhatikan dalam menerapkan hukum agar tetap memperhatikan ketertiban sebab tanpa ketertiban penerapan hukum dan penegakan hukum dapat berakhir dengan anarkis.

Ketaatan suami yang mengajukan permohonan poligami ke Pengadilan Agama dengan mengemukakan alasan yang sesuai dengan hukum formal dan pengadilan memutus apakah diterima ijinnya atau ditolak dalam bentuk penetapan memberikan pengaruh tidak hanya pada para pihak tapi juga pada masyarakat. Ketaatan para warga masyarakat terhadap aturan hukum merupakan cerminan budaya hukum (legal culture). Budaya hukum masyarakat turut memberikan peran menciptakan ketaatan hukum. ${ }^{4}$

Lawrence Friedman dalam buku The Legal System memandang system sebagai on operating unit with definite bouderies. Memahami kata system sebagai on operating unit mensyaratkan gerak dinamisasi antar pelbagai

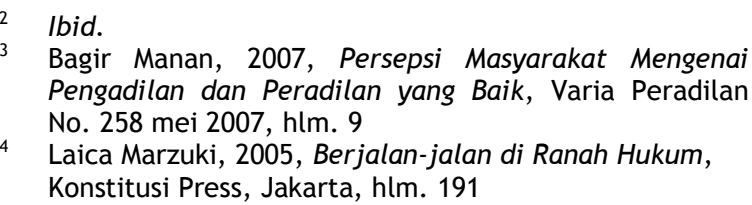

komponen pendukung sistem (Sistem menurut Kamus Besar Bahasa Indonesia dipahami sebagai seperangkat unsur yang secara teratur saling berkaitan sehingga membentuk totalitas).

Tiga komponen pada sistem hukum (legal system) yaitu subtansi (subtance or the ruler) struktur (structure) dan budaya hukum (legal culture) berfungsi ibarat jentara yang menggerakan kincir padi, bila salah satu tidak berfungsi niscaya kincir mengalami disfunction (pincang).

Poligami dengan berbagai karakteristeriknya yang unik yang dikenal dalam Islam dan telah diujudkan dalam Undang-undang Perkawinan dan berbagai peraturan pelaksanaanya dalam implementasinya terdapat dua kepentingan yang saling berlawanan.

Menurut Bagir Manan dalam perkara perdata tidak dibenarkan hakim mengedapankan kepentingan masyarakat daripada kepentingan pihak-pihak (individu), kepentingan masyarakat harus ditempatkan dibelakang kepentingan pihak-pihak. ${ }^{5}$ Apabila ada perbedaan antara kepentingan keadilan yang berperkara dalam hal ini misalnya istri yang memberikan ijin dengan rasa keadilan, hakim wajib mendahulukan kepentingan dan keadilan yang berperkara, kecuali benar-benar dapat ditunjukan secara nyata suatu kepentingan masyarakat tanpa merugikan kepentingan dan rasa keadilan yang berperkara.

\section{Penutup}

Implementasi tentang ijin poligami yang diajukan suami ke Pengadilan Agama dengan alasan-alasan dan syarat-syarat hukum yang dipenuhi dan tidak melanggar ketentuan hukum Islam. Pengadilan Agama akan memeriksa, mengadili dan memutuskan dengan penetapan yang isinya mengabulkan ijin poligami yang diajukan dengan pertimbangan untuk kemaslahatan para pihak sesuai dengan ajaran Islam. 


\section{Daftar Pustaka}

Arto, Mukti, 1995. Praktek Perkara Perdata pada Pengadilan Agama. Yogyakarta: Pustaka Pelajar;

Manan, Bagir. 2007. Persepsi Masyarakat Mengenai Pengadilan dan Peradilan yang Baik. Varia Peradilan, No. 258. Jakarta: IKAHI;

Manan, Abdul. 2005. Penerapan Hukum Acara Perdata di Lingkungan Peradilan Agama. Jakarta: Kencana, Prenada Media Group;

Marzuki, Laica, 2005. Berjalan-jalan di Ranah Hukum, Jakarta: Konstitusi Press;
Mertokusumo, Sudikno. 2005. Hukum Acara Perdata, Yogyakarta: Liberty;

-.--.--.. 2001. Penemuan Hukum Sebuah Pengantar. Yogyakarta: Liberty;

Wanta, M. Fence. 2007. Antinomi dalam Penegakan Hukum oleh Hakim. Mimbar Hukum Vol. 19 No. 3 Yogyakarta: FH UGM. 